\title{
GALILEO GALILEI \\ (1564-1642)
}

VASSÁNYI MIKLÓS

Firenzei olasz nemes (nobile fiorentino), feltaláló, hadmérnök, fizikus, csillagász, matematikus, természetfilozófus, humanista, a pisai, majd a padovai egyetem professzora, Kepler, Clavius, Campanella levelezőtársa, Torricelli tanára, az 1603-ban alapított római tudományos akadémia, az Accademia dei Lincei tagja. A zenészcsaládba született Galilei 1574-ben családjával együtt Firenzébe költözött. 1580-tól 1585-ig orvosi tanulmányokat végzett a pisai egyetemen, de nem szerzett fokozatot. Legkorábbi kéziratai (Iuvenilia, 1584, Edizione Nazionale - a továbbiakban EN - I) még az aristotelési kozmológia szellemében fogantak. Első fizikatudományi kézirata a Theoremata circa centrum gravitatis solidorum (Elméletek a szilárd testek nehézkedésének középpontjáról, 1585, EN I). Galilei 1589-től 1592-ig a pisai egyetemen oktatott eukleidési geometriát és ptolemaiosi csillagászatot. 1592-től 1610-ig a padovai egyetemen tanított matematikát. Ekkor írta a Trattato della Sfera ovvero Cosmografia („Értekezés a szféráról, avagy kozmográfia”) című, még ptolemaiosi szellemü értekezését. 1597-ben váltott először levelet Keplerrel, kifejtve, hogy régóta meggyőződéses kopernikánus, jóllehet titkolja ezt a meggyőződését (EN X, № 57, 68). 1609-ben értesült a távcső feltalálásáról, és a hírek alapján megépítette első távcsövét. Galilei írta a távcső csillagászati használatáról szóló első nyomtatott müvet, a Sidereus nunciust („Csillaghírnök”, 1610). Cosimo II de’ Medici toszkán nagyherceg ezután udvari matematikusának és filozófusának nevezte ki. Kepler 1610-ben a Dissertatio cum Nuncio sidereo („Beszélgetés a Csillaghírnökkel”, Prága) című rövid írásával fejezte ki óvatos támogatását Galilei felfedezései iránt. Galilei 1613-ban írta a napfoltok mozgását rengeteg metszettel ábrázoló Istoria e dimostrazioni intorno alle macchie solari e loro accidenti („,Kutatás és bizonyítások a napfoltokról s azok változásairól") címü vitairatát, mely bizonyította a Nap tengely körüli forgását. A Biblia értelmezéséről szólnak nevezetes „kopernikánus levelei” (lettere copernicane): 1613-ban tanítványához, Benedetto Castelli bencés atyához, 1615-ben Piero Dinihez, Galilei római pártfogójához és Cristina di Lorenához, Cosimo II de’ Medici nagyherceg anyjához (mind EN V). 1614 ádventjén a firenzei Santa Maria Novella domonkos kolostor szerzetese, Tommaso Caccini a szószékről támadta, és az inkvizíciónál fel is jelentette Galileit heliocentrizmusáért. Galilei 
1615-ben Rómába utazott, hogy pártfogókat keressen. Itt írta 1616-ban a Discorso del flusso e reflusso del mare („Értekezés a tenger dagályáról és apályáról; EN V) címü levelét, mely az árapály jelenségéből kívánta bizonyítani a Föld Nap körüli keringését és napi körforgását. V. Pál pápa azonban teológiai vizsgálóbizottságot hívott össze a következő két tétel vizsgálatára, „hogy a Nap van a világ középpontjában, s következésképp helyváltoztató mozgással nem mozog;” és „hogy a Föld nem a világ középpontja, és nem is mozdulatlan, hanem teljes egészében mozog, még napi mozgással is". A kijelölt, 11 fös ad hoc bizottság öt napi megfontolás után 1616 február 24-én a következő határozatot hozta: A Nap mozdulatlanságáról szóló tézis „ostoba és abszurd filozófiailag, és formálisan eretnek, mivel kifejezetten ellentmond a Szentírásnak;” a Föld mozgásainak tana „ugyanígy abszurd filozófiailag, és a teológiai igazság tekintetében legalábbis hitben téves”. Másnap - a korábban Giordano Bruno perében is részt vevö - Bellarmino bíboros behívatta palotájába Galileit, és a föinkvizítor jelenlétében felszólította a két tézis feladására. Galilei elfogadta a figyelmeztetést, s megígérte, hogy engedelmeskedik. Az Index-Kongregáció 1616. március 5-én határozatban ítélte el a Nap mozdulatlanságát és a Föld mozgását hirdető tanokat, és felfüggesztette „Copernicus $A z$ égi pályák körforgásairól címü müvét, amíg ki nem javíttatik." Galilei hazatért Firenzébe, ahol 1619-ben tanítványával, Mario Guiduccival együtt írta a Discorso delle cometét („Beszéd az üstökösökről”, EN VI), melyben tagadja az üstökösök valóságát, légköroptikai jelenségeknek tartva őket. Orazio Grassinak, a Collegium Romanum matematikusának ezt elítélö írására (Libra astronomica ac philosophica, Perugia, 1619) az Il saggiatore címü mủvel válaszolt (A próbamester, Róma: 1623, EN VI). A levélformában írott szöveg elnyerte az új pápa, VIII. Orbán (sedit 1623-1644) tetszését is. Galilei 1624-ben Rómába utazott, hogy kipuhatolja, a heliocentrizmus tárgyalására vonatkozó tiltás érvényben van-e még. A pápa többször fogadta, és ajándékokkal is kitüntette. Galilei Firenzébe visszatérve válaszolt Francesco Ingoli ravennai teológus levelére a Lettera a F. Ingoli in risposta alla De situ et quiete Terrae címü levelével (Levél F. Ingolihoz a Föld helyzetéröl és nyugvásáról, 1624, EN V), majd 1625-ben új kéziratot írt az árapályról, melyben a Hold módosító hatásával egészítette ki az 1616-os Értekezésében közölt elméletet, s amely fő műve záró párbeszéde lett. A Dialogo di Galileo Galilei Linceo matematico sopraordinario dello Studio di Pisa... dove ne i congressi di quattro giornate si discorre sopra i due massimi sistemi del mondo Tolemaico, e Copernicano (Firenze, 1632, EN VII, magyarul Párbeszédek a két legnagyobb világrendszerröl, a ptolemaiosziról és a kopernikusziról - a teljes szöveg egyötödét fordította Zemplén Jolán sok hibával, Budapest, 1959) megjelenését a pápa azzal a feltétellel engedélyezte, hogy Galilei a mű címében nem utal az árapályra (az eredeti szerzői cím Dialogo del flusso e riflusso del mare, „A tenger dagályáról és apályáról” lett volna); hipotézisként kezeli a heliocentrikus modellt; és beilleszti a szövegbe a pápai titkár által írandó bevezetést és 
lezárást. A kijelölt cenzorok a szükséges javítások után jóváhagyták az ekkor Galileinél lévő szövegvariánst. Galilei azonban Firenzébe való visszatérte után jelentősen átírta a kéziratot, amelyet végül - egy pestisjárvány miatt - Róma helyett Firenzében nyomtatott ki, ahol a helyi inkvizítor figyelmét elkerülte, hogy Galilei nem tartotta be a pápa által szabott feltételeket. VIII. Orbán 1632 júliusában betiltotta a könyvet, az inkvizíció pedig Rómába rendelte Galileit. Inkvizíciós perének első tárgyalását 1633. április 12-én tartották; Galilei ezután még négy alkalommal tett vallomást. Az 1633. június 22-én meghozott ítélet két pontban találta eretnekgyanúsnak (sospetto d’heresia) Galileit: egyrészt a Nap mozdulatlanságának és központi helyzetének, másrészt a Föld mozgásának és középponton kívüli helyzetének tanításában - mivel ezek ellentmondanak a Szentírásnak. Az ítélet betiltotta a Dialogót, szerzőjét tanai nyilvános visszavonására és megátkozására kötelezte, és meghatározatlan idöre az inkvizíció római börtönébe vetette. A hetvenéves matematikus az ítéletet aláíró hét kardinális előtt térden állva, eskü alatt, kezét az Evangéliumra helyezve vonta vissza és átkozta meg heliocentrikus tanait. Galileit később korára és egészségi állapotára való tekintettel börtön helyett házi őrizet alá helyezték a toszkán nagyherceg római palotájában, majd 1633 júliusától Sienában, végül Galilei villájában, a Firenze melletti Arcetriben. Az ítéletet a katolikus országok egyetemein a helyi inkvizítorok kihirdették a matematika- és filozófiaprofeszszorok előtt. Ez tette óvatossá Descartes-ot is, aki a Filozófiai alapelvek III. részében (Amszterdam, 1644) - a mozgás vulgáris, illetve tudományos fogalmának megkülönböztetése révén - a Nap központi helyzete mellett a Föld mozdulatlanságát állította. Galilei már Sienában elkezdte írni utolsó nagy müvét, a négy napi beszélgetésre osztott Discorsi e dimostrazioni matematiche intorno a due nuove scienzét (magyarul Matematikai érvelések és bizonyítások két új tudományág, a mechanika és a mozgások köréböl, 1986, röviden Két új tudomány, EN VIII). Eközben 1635-ben Strassbourg-ban Systema cosmicum cím alatt kiadták a Dialogo latin fordítását. A Discorsi e dimostrazioni ezután jelent meg Leidenben 1638-ban, miután Galilei már 1637 nyarán megvakult fél szemére. Kiterjedt levelezése 11 kötetet tölt meg az Edizione Nazionaléban (X-XX). Galilei emlékének szentelt tudománytörténeti múzeum és kutatókönyvtár a firenzei Museo Galileo az Arno partján.

Galilei különösen a Csillaghírnökben, a Cristina di Lorenához írott levelében, a Párbeszédben, A próbamesterben s a Két új tudományban fejtett ki gyökeresen új természet- és tudományfilozófiai, illetve biblikus hermeneutikai nézeteket. A csupán 52 oldalas Csillaghírnök Galilei első nyilvános, de óvatos állásfoglalása a kopernikuszi világrend mellett, amely szerint a szublunáris és a szupralunáris szféra valójában nem különíthető el, és nem minden égitest kering a Föld körül, hiszen legalábbis a Jupiter holdjai nem ezt teszik.

A Cristina di Lorenának címzett „kopernikánus” levélben Galilei nyíltan megfogalmazza heliocentrikus meggyőződését és bibliaértelmezési elveit. Miu- 
tán az Îrás fő célja az Isten iránti tisztelet és a lelki üdv biztosítása, ezért természeti kérdésekben nem törekszik a tudományos igazság közlésére, hanem úgyszólván „lefelé”, a hétköznapi tudat értelmi szintjéhez igazodik. Amikor nem hit és erkölcs dolgáról van szó, a bizonyított tudományos igazság alapján kell értelmezni a szent szöveget, mert Isten nem nyilatkozhat az érzékeléssel és az ésszel szemben, mely képességekkel Ő maga ruházott fel bennünket. A Levél követeli a szabad, autonóm tudomány lehetöségét (il libero filosofare circa le cose del mondo e della natura).

Galilei legolvasottabb műve, a Párbeszéd három szereplő négy napi beszélgetését rögzíti, csupán valószínűségi eredményre jutva. Az Első Nap fő tézise szerint - az aristotelési csillagászat alapvetésével szemben - a Föld nem különbözik a szupralunáris szféráktól, mivel az égbolt valójában nem változatlan, amint ezt az üstökösök, novák és a napfoltok tanúsítják. Galilei megkérdőjelezi az aristotelési fizika tanítását a négy elem egyenes vonalú természetes mozgásairól is, és bizonyíthatatlannak nevezi az aristotelési-ptolemaiosi posztulátumot a Föld középponti helyzetéről a világban. A Második Nap szerint a Föld naponta megfordul a saját tengelye körül - a Föld mozdulatlanságát ugyanis se Aristotelés, se Ptolemaios nem bizonyította szigorúan, és nem is lehet bizonyítani. Bolygónk ezért ugyanúgy „mozgó és bolyongó gömb, mint a Hold, a Jupiter és a Vénusz.” A mozgásjelenségek elemzése során Galilei megfogalmazza a tehetetlenség törvényét: $\mathrm{Az}$ egyszer mozgásba hozott, ideálisan gömbölyü test egy végtelen vízszintes síkon mindaddig gurul, amíg ellenállásba nem ütközik. A Második Nap következtetése azonban csupán negatív: A Földön magán nem végezhető olyan kísérlet, mely egyértelmüen bizonyítaná a Föld napi forgását. A Harmadik Nap fö tézise szerint a Föld éves mozgással körpályán kering a Nap körül (Galilei hallgat a Kepler által 1609-ben közölt felfedezésről, mely szerint a bolygópályák ellipszis alakúak). Galilei felvázolja a Naprendszer részletes modelljét, azzal a következtetéssel, hogy csak a kopernikuszi modell teszi lehetővé a részek harmóniáját a világrend egészében. A Negyedik Nap szerint a Föld napi és éves mozgásának fö bizonyítéka az árapály. Galilei itt felveti és eldöntetlennek mondja az aristotelési szférák mibenlétének kérdését. Az egész mű összefoglalásaként három fö érvet emel ki „a kopernikuszi rendszer mellett”: Ezek „a bolygók megállása és visszafelé haladása és váltakozó távolságuk a Földtől; másodszor a Nap tengely körüli forgása és az, ami a foltjaiban megfigyelhető; harmadszor a tenger dagálya és apálya”. A Párbeszéd nem tekinti megfontolásra érdemes alternatívának a Tycho Brahe-féle geo-heliocentrikus elgondolást, de részletesen és igazságosan tárgyalja a két fő rendszer mellett és ellen szóló összes lehetséges érvet, bár Galilei preferenciája a kopernikuszi modell iránt egyértelmü. A tárgyalás bizonyítja, hogy az aristotelési-ptolemaiosi csillagászat koherens alternatíva, melynek egyes előfeltevéseit nem lehet ugyan ellentmondás nélkül tagadni, de az egész rendszert minden előfeltevésével együtt lehet. A Pár- 
beszéd fó célja így rámutatni az aristotelési fizika és csillagászat korlátoltságára és következetlenségeire.

A VIII. Orbánnak ajánlott Próbamesterben Galilei vitriolos, kioktató hangvételben cáfolja vagy inkább kigúnyolja Orazio Grassi Libra astronomica ac philosophicájának állításait. A szöveg fö szakaszában rámutat, milyen választási lehetőségei voltak az Index-Kongregáció 1616-os határozata után egy katolikus csillagásznak: Miután Ptolemaios tanítása egyre lehetetlenebbnek látszott Kepler Mars-megfigyelései nyomán, Copernicust pedig tilos volt követni, sokan Brahe geo-heliocentrikus rendszerét képviselték.

A Két új tudomány a Párbeszédből ismert három szereplő négy napra tagolt beszélgetését rögzíti. Az első két nap témája a mechanika, közelebbről a - szilárd testek törési ellenállása kapcsán kifejtett - anyagelmélet, mely szerint az anyag bármely tetszőleges darabja végső soron végtelen sok nagyság nélküli és oszthatatlan részecskéből áll. A Harmadik és a Negyedik Nap a dinamikával foglalkozik. A Harmadik Nap először az egyenletes, majd az egyenletesen gyorsuló mozgás törvényeit határozza meg részletes geometriai bizonyításra épülő matematikai formulákkal, Eukleidés Elemeire emlékeztető módon. Eszerint a geometriai tulajdonságok összefüggenek a mozgás tulajdonságaival (út, idő, sebesség, gyorsulás), vagyis a geometria és a kinematika egymásba ágyazottak. A Negyedik Nap a lövedékek egyenletes és egyenletesen gyorsuló mozgásból összetett mozgását parabolikus görbeként határozza meg. Egy meghatározatlan Platón-hivatkozás (Timaios 38c-39e?) kapcsán Galilei felvázol egy teremtéselméletet is: eszerint Isten geometriai-kinematikai törvények figyelembe vételével ejtette helyükre a bolygókat - ez az elgondolás távolról rokonítható azzal, ahogyan Kepler ír a "geometrizáló Isten"-ről a Harmonice mundiban; illetve ahogyan Newton magyarázza a bolygómozgások közös jellemzőit a Four Letters to Dr Bentley-ben.

Galilei egyszerre volt matematikus, mérnök és technikus. Az összekötő kapocs e területek között a geometria: Galilei Platón Timaiosához hasonló módon minden természeti jelenségben meglátta a geometriai mintát. Bár az isteni kinyilatkoztatás egy fajának tartotta a természetet, Keplertől eltérően nem indult ki közvetlenül Isten természetéből a természet megértésében. Éleslátása révén Aristotelés mögé tudott kérdezni éppen azáltal, hogy következetesen és egységben gondolta végig Aristotelés téziseit. Ezzel elkerülhetetlenül kihívta maga ellen a korabeli, peripatetikus filozófiával felvértezett teológia ellenállását. Elítélésében azonban szerepet játszott a pápa személyes sértettsége is az árapállyal kapcsolatos véleményének rossz beállítása miatt a Párbeszéd zárásában. Az inkvizíció ítéletének szövegében észre kell vennünk, hogy a vád csak a Szentírásnak való ellentmondás volt; és hogy az indoklás tartózkodott a kérdés tudományos lényegének megközelítésétől. Másfelől paradox, hogy Galilei egy olyan elméletben - az árapály sajátos magyarázatában - vélte megtalálni a heliocentrizmus legfőbb bizonyítékát, 
amely téves volt. Az árapály jelenségét végül Newton vezette vissza a Hold és a Nap gravitációs hatására, az egyetemes tömegvonzás keretei közé helyezve el azt (Philosophiae naturalis principia mathematica - A természetfilozófia matematikai alapelvei, III. könyv, 24. tétel, 1687). Galilei munkássága ettől függetlenül szinte áttekinthetetlenül nagy, szerepe az alkalmazott geometria, az anyagelmélet, a mechanika, a dinamika, a csillagászat történetében felmérhetetlen. A kopernikuszi világkép elfogadásához döntően járult hozzá a Csillaghírnökben és a Kutatás és bizonyítások a napfoltokról-ban közölt távcsöves megfigyeléseivel, és különösen a Párbeszédben részletesen taglalt csillagászati érveivel, melyeket az egész világ megismerhetett a mű latin fordításából. Kísérletező kutatási módszere megelőlegezte Francis Bacon tudományos módszertanát, biblikus hermeneutikája pedig a természettudományok autonómia-törekvését segítette elő.

\section{TOVÁBBI IRODALOM}

Edizione Nazionale I-XX. (1890-1907): galileoteca.museogalileo.it/GTConsult/index.xhtml Galilei, Galileo: Scienza e religione. Scritti copernicani (2009).

Heilbron, John: Galileo (2010).

Koyré, Alexandre: Études galiléennes I-III. (1935).

Pagano, Sergio (ed.): I documenti del processo di Galileo Galilei (1984). 